\title{
Charles Nodier, Promenade de Dieppe aux montagnes d'Écosse
}

\section{Lise Sabourin}

\section{Q OpenEdition}

10 Journals

\section{Édition électronique}

URL : http://journals.openedition.org/studifrancesi/33377

DOI : 10.4000/studifrancesi.33377

ISSN : 2421-5856

Éditeur

Rosenberg \& Sellier

\section{Édition imprimée}

Date de publication : 1 décembre 2005

Pagination : 658

ISSN : 0039-2944

\section{Référence électronique}

Lise Sabourin, "Charles Nodier, Promenade de Dieppe aux montagnes d'Écosse », Studi Francesi [En ligne], 147 (XLX | III) | 2005, mis en ligne le 30 novembre 2015, consulté le 20 avril 2021. URL : http:// journals.openedition.org/studifrancesi/33377 ; DOI : https://doi.org/10.4000/studifrancesi.33377

Ce document a été généré automatiquement le 20 avril 2021.

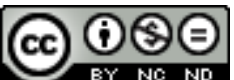

Studi Francesi è distribuita con Licenza Creative Commons Attribuzione - Non commerciale - Non opere derivate 4.0 Internazionale. 


\title{
Charles Nodier, Promenade de Dieppe aux montagnes d'Écosse
}

\author{
Lise Sabourin
}

\section{RÉFÉRENCE}

CHARLES NODIER, Promenade de Dieppe aux montagnes d'Écosse, édition établie et commentée par Georges Zaragoza, Paris, Honoré Champion, 2003, pp. 182

Depuis 1821 n'avait pas été republié ce texte important, né de la redécouverte de l'Écosse par les voyageurs britanniques et français du XVIII siècle, mais aussi de la sensibilité artistique de Nodier face à ce pays nimbé d'aura littéraire. Née de l'amitié avec le baron Taylor et Alphonse de Cailleux - les inventeurs avec lui des Voyages pittoresques dans l'ancienne France, au concept novateur sur le plan touristique mais aussi pour l'histoire des idées, cette entreprise est liée au rayonnement d'Ossian et Scott auprès des romantiques.

2 Pèlerinage littéraire donc, mais aussi animé par le souci de conservation des monuments, ce voyage influence fortement la gestation de Trilby et de La Fée aux miettes, avant d'inspirer en 1825 le Voyage historique et littéraire en Angleterre et en Écosse d'Amédée Pichot. On pense au futur Voyage à reculons en Angleterre et en Écosse qui nourrira bien des romans de Jules Verne, dont Les Indes noires et Le Rayon vert.

Georges Zaragoza enrichit le texte original des variantes et suppléments du manuscrit, le met en perspective par des documents (préface des Voyages, lettres à sa femme, articles sur Scott, extraits des Questions de littérature légale et Épisodes et souvenirs de la vie de Nodier par sa fille, Marie Mennessier), offre un index des noms de personnes et de lieux.

4 La composition de la Promenade opère des regroupements au sein des notes prises au jour le jour, inversant des visites pour mieux les lier, effaçant des détails biographiques, autocensurant des émotions. Renouvelant la tradition rousseauiste, cette méthode de Nodier interroge sur la mise en forme littéraire de la sensibilité romantique, contribue 
à une profonde modification du genre et invite à réflexion sur la relation entre journal intime, récit de voyage et fiction. 